Jahrbuch für Geschichte Lateinamerikas

Anuario de Historia de América Latina

58 | $2021 \mid 1-6$

Cristóbal Aljovín de Losada

David Velásquez Silva

Universidad Nacional Mayor de San Marcos

Ideología, imaginarios y violencia política en los Andes durante el siglo XIX
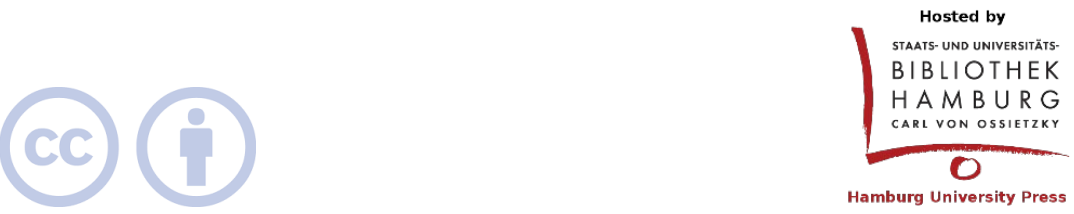

Except where otherwise noted, this article is licensed under a

Creative Commons Attribution 4.0 International license (CC BY 4.0)

https://doi.org/10.15460/jbla.58.234 


\title{
Ideología, imaginarios y violencia política en los Andes durante el siglo XIX
}

\author{
Cristóbal Aljovín de Losada \\ David Velásquez Silva
}

El presente dossier consta de 6 artículos que exploran la relación entre la violencia política y los aspectos ideológicos e imaginarios de la política en los países andinos (las actuales repúblicas de Bolivia, Perú, Ecuador y Colombia). En estos estudios, partimos de la premisa que cualquier acto político de índole pacífico o violento tiene fuertes componentes ideacionales y retóricos que los justifican y dan forma. Los actos de violencia política están insertos en marcos de significados que expresan determinadas culturas políticas y/o imaginarios políticos, con contenidos ideológicos identificables o no, que sirven para justificarlos, permiten la movilización y delinean las estrategias y las identidades de los actores. Normalmente, estos marcos varían mucho, dependiendo del ángulo del actor histórico y de las circunstancias específicas en las que tienen lugar. Todo movimiento político de cierta envergadura tiene múltiples aristas y concepciones diferentes. No hay que ser naive para pensar que una movilización tiene una posición homogénea. Cuando más grande sea la movilización, mayor heterogeneidad de sus agendas. Asimismo, las posiciones van cambiando con la lucha o con las sumas o restas de los actores históricos que no son fáciles escudriñar (véase Soux, Aljóvín-Velasquez, Escobar y Mendieta). A ello se debe añadir que estas herramientas de significado pueden cambiar, reutilizarse o convivir con nuevos repertorios si se observan en forma comparada diversos movimientos políticos a lo largo de las décadas (véase Espinosa y Escobar).

Usualmente, cuando los historiadores nos acercamos a los marcos ideacionales y retóricos, nos vemos casi obligados a recurrir a los registros del mundo letrado. Sin embargo, no hay que dudar que la naturaleza de la lucha política y de los intereses de los actores no debe agotarse en una aproximación a las élites; sino incluir a los demás sectores sociales. Como confirman los artículos de este dossier, todos los movimientos de la América andina postindependiente recurrieron 
retóricamente y en la praxis política, en la paz y en la guerra, a ese pueblo soberano que, abstracto en sus constituciones y en los escritos de sus élites, requería un mínimo de concreción en los hechos, ya sea luchando en los campos de batalla, ya sea en las calles o en los clubes políticos. Por su puesto, el acercamiento a la politización de los diferentes sectores de la sociedad no debe ser fruto de una interpretación ingenua y mecánica de sus motivaciones. Interpretar la agencia de los diversos sectores, incluyendo los sectores plebeyos, implica también incorporar al análisis su comprensión de la retórica política y de sus propios intereses que deben ser aprehendidos en escenarios inestables y en movimientos que obligan superar las fáciles adscripciones de clase o partidarias con las que los historiadores hemos tratado, hasta no hace mucho, de encuadrar sus acciones.

A pesar de ello, no escapa a los estudios de este dossier poner el acento en la dimensión de los intereses de los actores, pues ningún estudio de la política puede hacer abstracción de ellos. Los intereses están presentes en los individuos y en los colectivos, en tanto que los principios y los intereses no son, comúnmente, excluyentes ${ }^{1}$ y su imbricación puede ser bastante plástica, dependiendo, eso sí, de las condiciones políticas y estratégicas en las que operan los actores (véase Soux, Escobar, Aljovín-Velásquez y Mendieta).

Al referirnos a los marcos de significado con los que los actores justificaron $\mathrm{y}$ dieron forma a los movimientos políticos que consideramos en este dossier, buscamos incorporar aquellos repertorios de ideas, símbolos, valores e imágenes que fueron empleados en la lucha política de las repúblicas andinas y que en las ciencias sociales habían sido considerados hasta no hace mucho como ideologías. Desde la década de 1970, en diversas disciplinas se ha discutido acerca de la pertinencia y utilidad de esta categoría para enmarcar el universo de las representaciones sociales, poniéndose en entredicho las definiciones propias del marxismo duro y esquemático, para quien las ideologías eran visiones del mundo destinadas a enmascarar las relaciones de explotación y dominación. Aproximaciones alternativas en deuda con la antropología cultural, la

1 Puede revisarse el debate entre Alan Knight y Cristóbal Aljovín y Nils Jacobsen en torno al análisis de las relaciones entre intereses y valores en la política andina. Cristóbal Aljovín / Nils Jacobsem (eds.), Cultura política en los Andes (17501950), Lima: IFEA, UNMSM, Embajada de Francia en el Perú, 2007, pp. 41-103. 
crítica literaria e incluso la historia de las mentalidades han permitido un giro hacia la dimensión simbólica de la vida social y la percepción de lo que los sujetos consideran como la realidad social y política, giro que, en términos gruesos, permite a los historiadores incorporar al análisis un conjunto de dimensiones culturales de la política bajo el concepto de imaginario.

El abordaje del imaginario, no obstante su pluralidad de enfoques comparte algunos elementos en común. En primer lugar, que las sociedades construyen dinámica y flexiblemente representaciones sobre sí mismas que están incrustadas en las relaciones sociales. Estas representaciones se expresan en el orden simbólico de múltiples maneras, ya sea por medio de imágenes, símbolos, rituales o metáforas. Segundo, los imaginarios son dinámicos, se originan magmáticamente de la interacción de los grupos sociales y de las acciones y producciones individuales que les dotan de contenidos y formas. Tercero, los imaginarios no se extienden de manera uniforme sobre una comunidad dada, ni es necesario que dicha extensión sea completa, pues pueden convivir, interactuar o competir con otros. Ello no implica paridad de fuerzas entre los actores y los grupos. Cuarto, son formas de imaginar la sociedad y son imágenes de la misma, como representaciones, no son enteramente descriptivas, pues están cargadas de expectativas, pretensiones normativas y de la plasticidad de la creatividad humana que no se deja aprisionar por la realidad ni la razón, sino que crea y recrea las imágenes en función de tales expectativas. ${ }^{2}$ Su dimensión imaginaria no significa que con ella se busca encubrir lo que es, aunque esto no niega que los actores y las ideologías busquen dar forma al imaginario. En los estudios de este dossier, los marcos ideacionales y retóricos más importantes giran en torno al imaginario republicano, que es extremadamente flexible.

A lo largo del siglo XIX, en el espacio andino como en el resto del mundo atlántico, van haciendo su aparición ideologías marcadas por las revoluciones Atlánticas, en especial la francesa de 1789. Desde la modernidad política, surgen pugnas ideológicas (por ejemplo, entre el liberalismo y el conservadurismo) con complejos matices y fervor pasionario que plantean futuros diferentes. Estas ideologías interpretan

2 Charles Taylor, Imaginarios sociales modernos, Barcelona: Ediciones Paidós Ibérica, 2006; Bronislaw Baczko, Los imaginarios sociales. Memorias y esperanzas colectivas, Buenos Aires: Ediciones Nueva Visión SAIC, 1999. 
el orden social y dan cuenta y justifican posiciones, intereses y relaciones de los actores políticos. Las adherencias ideológicas son flexibles y se expresan con diferentes grados de intensidad. A diferencia de los imaginarios, las ideologías políticas pretenden ser sistemáticas, buscan construir una lectura codificada y coherente de la realidad y ofrecen justificaciones racionales o racionalizadas de la organización del poder. Al mismo tiempo se alimentan y buscan dar forma a los imaginarios sociales.

Las ideologías generan identidades políticas, dan coherencia interna en materia de principios a sus miembros y al mismo tiempo los distinguen de los otros. Sin embargo, la experiencia en las últimas tres décadas de estudio sobre la vida política andina nos muestra la ductilidad de los actores, sus ideas y sus prácticas. Hay como es comprensible diversos liberalismos y grados de conservadurismo. De modo interesante, Sobrevilla resalta la tradición liberal (antimilitar) en el Perú como un componente fundamental de la lucha política en que se contraponen con los defensores del orden. La redacción de las constituciones decimonónicas también reflejaba este conflicto. En el mundo Atlántico, incluyendo los Andes, se estaban construyendo los idearios y las identidades políticas de lo que más adelante serían llamados modernamente como partidos políticos y sus ideologías. Es con las guerras de independencia, y posteriormente con el nacimiento de las repúblicas que aparece la combinación entre violencia política y con estos marcos ideológicos (véase Soux y Sobrevilla). Sin embargo, en la década de 1840 y, especialmente, con la revolución de 1848, se produce un corte de orden político que implicó un afianzamiento o la creación de nuevas identidades. La impronta de esta revolución no sólo tuvo efectos en el viejo continente, en América los postulados de sus propugnadores y detractores tuvieron impactos importantes en la definición de las identidades políticas. ${ }^{3}$

La violencia política formó parte de la cultura política en los países andinos durante el siglo XIX. Esta adoptó distintas formas y se ejerció en diferentes escalas que podían ir desde conflictos específicos, meramente locales, hasta conflagraciones de carácter nacional que tomaban la forma de verdaderas guerras civiles. A diferencia de lo que sucedía por esos años en Europa, en América andina las guerras

${ }^{3}$ Guy Thomson (ed.), The European Revolutions of 1848 and the Americas, Londres: Institute of Latin American Studies, 2002. 
internacionales fueron escasas, en marcada diferencia con el abultado número de conflictos armados internos. ${ }^{4} \mathrm{Y}$ aunque el uso de las armas fue cuestionado constantemente por los actores como método para arbitrar la política, ya sea por los males que generaba, tácita o explícita fue reconocida ésta como la última ratio y, por tanto, legítimo su uso en determinadas circunstancias.

El uso de las armas siempre requirió estar envuelta en palabras e imágenes que ofrecieran un futuro mejor a los combatientes en el campo de batalla o fuera de él y, de igual modo, hicieran posible construir la imagen del enemigo político que justificaba el uso de la violencia (Véase Aljovín-Velásquez, Soux y Espinosa). Carlos Espinosa observa cómo el republicanismo clásico formó parte del repertorio discursivo. Sin embargo, el republicanismo clásico estuvo amarrado al lenguaje político inaugurado por las revoluciones Atlánticas y, en pocas palabras, este repertorio estuvo inserto en lo político propio del siglo XIX para justificar las revoluciones.

Existió una relación compleja en las escalas de la violencia política, pues las guerras civiles podían alimentarse, en su origen y desarrollo, de conflictos locales preexistentes o, por el contrario, generar las condiciones para su ejercicio en espacios locales. Dentro de la movilización armada, además de la violencia política dirigida a objetivos o rivales identificados, se podían esconder otros usos motivados por agendas diferentes que en conjunto alimentan el caudal del uso de la fuerza. Como es de esperarse, en estos movimientos existían diversos tipos de violencia (Véase Escobar y Mendieta).

No han sido frecuentes los casos de politización de los plebeyos que, movilizados de manera autónoma a las élites, recurrieron a la violencia para reivindicar sus propias agendas. No existió, por lo menos en el siglo XIX, una acción colectiva de los sectores populares comparable a la que va adquiriendo forma en Europa desde la segunda mitad de la centuria. Por ello, los discursos, en su mayoría, estuvieron dirigidos a diferentes grupos sociales de quienes se esperaba su movilización por medio de la persuación o la fuerza. Sin embargo, los análisis locales nos muestran también aspectos de cierta autonomía plebeya. Mendieta propone cruzar el discurso liberal con la cultura política indígena para comprender el gobierno político de Peñas en 1899. Escobar, en cambio,

\footnotetext{
4 Miguel Ángel Centeno, Sangre y deuda. Ciudades, estado y construcción de nación en América Latina, Bogotá: Editorial Universidad Nacional de Colombia, 2014.
} 
busca comprender por qué un grupo humano lucha por un bando u otro durante la guerra de los Mil Días, y encuentra la respuesta en la dinámica y los intereses locales, escapando, en gran medida, de la narrativa que privilegia a los grandes actores.

¿De qué manera las ideologías se relacionaban con la cultura política/imaginarios políticos? ¿Cómo se construye la argumentación del uso de la violencia política? ¿Qué tipo de repertorios fueron utilizados para desconocer la autoridad y lanzarse al uso de las armas? ¿Cómo se construían solidaridades políticas más allá de las identidades partidarias? ¿De qué manera se relacionaron en estos combates lo local, lo nacional y lo transnacional? Son preguntas que valen la pena responder. En este dossier, como se verá en sus artículos, buscamos poner de relive cómo las acciones armadas estuvieron envueltas en palabras, imágenes y símbolos. Mostrar cómo intervienen los marcos ideacionales y retóricos, los imaginarios y las ideologías partidarias y de qué manera permiten estas legitimar la acción política violenta y la movilización de diversos grupos sociales y políticos en el espacio andino decimonónico. 